\title{
Changes in abundance and community structure of bacteria associated with buoyant Microcystis colonies during the decline of cyanobacterial bloom (autumn-winter transition)
}

\author{
Limei Shi, Yuanfeng Cai, Fanxiang Kong* and Yang Yu
}

State Key Laboratory of Lake Science and Environment, Nanjing Institute of Geography and Limnology, Chinese Academy of Sciences, 73 East Beijing Road, Nanjing 210008, P.R. China

Received 27 January 2011; Accepted 14 April 2011

\begin{abstract}
The structure and composition of the bacterial community associated with buoyant Microcystis colonies were monitored during the decline of a cyanobacterial bloom (from October 13, 2009 to January 27, 2010). When temperature decreased, the ratio between the colony-associated bacteria and the Microcystis gradually decreased as estimated by a quantitative real-time polymerase chain reaction (qRT-PCR)-based approach. Diversity of bacterial communities was determined through denaturing gradient gel electrophoresis (DGGE) of 16S rRNA gene fragments. Cluster analysis of the DGGE profiles showed that most of the bacterial communities associated with Microcystis colonies collected on the nearby dates were clustered together. The bacterial clones from four clone libraries in different months were classified into 5, 12, 6 and 12 operational taxonomic units, most of which were affiliated with Gammaproteobacteria, Alphaproteobacteria and Bacteroidetes. Shift in dominance from pathogenic Aeromonas sp. to Shewanella sp. capable of remineralization of many organic materials was observed, and both species seemed to be associated with Microcystis colonies along with the bloom decline. These results indicated that the potential harmful effects of the Microcystis bloom on the safety of lake water during the decline period should be taken into account.
\end{abstract}

Key words: Microcystis / associated bacteria / abundance / diversity / decline

\section{Introduction}

Microcystis is a common and ubiquitous bloomforming cyanobacterial genus in eutrophic freshwater lakes. Microcystis often dominates the phytoplankton during summer, declines in late autumn when the temperature is low, then begins recovering the next spring (Reynolds et al., 1981). Many temperate lakes annually suffer from overabundant cyanobacterial blooms.

Microcystis colonies often live in association with numerous bacteria (Pearl, 1988; Bostroëm et al., 1989). Substances released from algal cells are trapped in the mucilage, which mainly consists of polysaccharide, because of the high viscosity of the mucilage (Amemiya et al., 1990). The colony sheath of Microcystis is assumed to be a hot spot compared to the surrounding water (Worm and Søndergaard, 1998). The contribution of Microcystisassociated bacteria constitutes $19-40 \%$ of the total bacterial abundance (Brunberg, 1999). The bacteria colonize Microcystis in old, as well as in young and

\footnotetext{
*Corresponding author: fxkong@niglas.ac.cn
}

healthy colonies. Symbiotic interactions may occur in the mucilage (Steppe et al., 1996). The exudates of Microcystis provide a source of substrates for attracting heterotrophic bacteria, and have an antibiotic effect on non-co-occurring bacteria (Casamatta and Wickstrom, 2000). On the other hand, bacteria might be able to provide beneficial metabolites to cyanobacteria through remineralized nutrients or lysing the cyanobacteria by excreting algicidal substances (Salomon et al., 2003).

Bacterial community composition changes along with the development of phytoplankton blooms (Riemann and Winding, 2001). Shifts in the species composition of the phytoplankton and attached bacterial communities have been linked in a coastal marine environment (Rooney-Varga et al., 2005). Several studies have reported that bacteria play a significant role in aquatic ecosystems as decomposers of phytoplankton (Sigee, 2005; Reynolds, 2006), and may terminate freshwater blooms (Manage et al., 2000; Rashidan and Bird, 2001). Significant changes in the bacterial community after viral-induced mass lysis of cyanobacterial blooms have also been reported (Van Hannen et al., 1999). Dissimilar bacterial communities 
may be favored by different cyanobacterial blooms even under similar environmental conditions (Eiler and Bertilsson, 2004). The specific association between Microcystis and bacteria has been documented by Shi et al. (2009). Interactions between Microcystis species and their associated bacteria in colonies, where bacterial-algal associations are more dense and abundant than free-living bacteria in the water column (Bell and Mitchell, 1972), may be a key to understanding their role in the cycling of organic and inorganic compounds and their ecological impact on bloom development. Understanding the bacterial communities associated with Microcystis and how they change during the bloom decline may help establish an understanding of the physiological status of Microcystis. Shifts in the bacterial community composition may affect the health of Microcystis and its susceptibility to decay.

The diverse presence of Alphaproteobacteria, Betaproteobacteria, Gammaproteobacteria, Deltaproteobacteria, Bacteriodetes and Actinobacteria in the water column in Lake Taihu during the Microcystis bloom event has been documented (Wu et al., 2007). The presence of Alphaproteobacteria, Betaproteobacteria, Gammaproteobacteria, Bacteroidetes, Firmicutes, Deinococcus-Thermus and Gemmatimonadetes associated with Microcystis colonies during the vigorous period of the bloom has been studied by Shi et al. (2010). However, little is known about the identity of bacteria that inhabit Microcystis colonies during the decline period, even though these organisms are involved in significant biodegradation processes and carbon dynamics (Burnberg, 1999). Thus, in the present study, the community structure of bacteria associated with Microcystis colonies collected during bloom decline is investigated for the first time. Their ecological role in the decline of cyanobacterial bloom is also discussed.

\section{Materials and methods}

\section{Sample collection}

During the bloom decline period (from October 13, 2009 to January 27, 2010), cyanobacterial samples were collected with plankton net (mesh size: $25-50 \mu \mathrm{m}$ ) from the surface water in Meiliang Bay $\left(31^{\circ} 43^{\prime} \mathrm{N}, 120^{\circ} 18^{\prime} \mathrm{E}\right)$ in the northern part of Lake Taihu in China, which is hypertrophic with annual Microcystis bloom. Once a month, dissolved oxygen (DO) and $\mathrm{pH}$ were measured in situ using a Yellow Springs Instrument water quality sonde (YSI 6600, USA). Total nitrogen (TN) and total phosphorus (TP) were analyzed according to standard methods (Jin and Tu, 1990), and phycocyanin was measured according to Asai et al. (2001). To separate these collected Microcystis colonies from other particles, samples were allowed to stand until most of the Microcystis colonies floated to the water surface. Only the colonies that floated to the water surface were collected by micropipetting. These colonies were then checked under a binocular microscope. To remove free-living bacteria, the samples were resuspended and washed 10 times on autoclaved
$20 \mu \mathrm{m}$ pore size nylon screen with autoclaved phosphatebuffered saline ( $\mathrm{pH}$ 7.2). About $10 \mathrm{mg}$ wet weight of the Microcystis colonies were transferred to $1.5 \mathrm{~mL}$ sterile Eppendorf tubes, and were then stored at $-20^{\circ} \mathrm{C}$.

\section{DNA extraction}

Community DNA extraction was conducted using the potassium xanthogenate sodium dodecyl sulfate (xs procedure) method, as described by Tillett and Neilan (2000).

\section{Quantitative real-time polymerase chain reaction (qRT-PCR)}

A qRT-PCR-based approach was used to estimate the ratios between the colony-associated bacteria and Microcystis. qRT-PCR was conducted with an Mastercycler Ep Realplex (Eppendorf, Germany) using SYBR Green PCR Master Mix kit (Qiagen, Valencia, CA). All reactions were carried out in a total volume of $25 \mu \mathrm{L}$ and amplified in triplicate. The universal bacterial primer pair Bac341F (5'CCTACGGGAGGCAGCA-3')/Bac518R (5'-ATTACCGCGGCTGCTG-3') was used to amplify the bacterial 16S rRNA gene under the following conditions: $95^{\circ} \mathrm{C}$ for $10 \mathrm{~min}$, followed by 45 cycles of $95^{\circ} \mathrm{C}$ for $1 \mathrm{~min}, 55^{\circ} \mathrm{C}$ for $30 \mathrm{~s}$ and $72^{\circ} \mathrm{C}$ for $1 \mathrm{~min}$. Using the primer pair Micr $184 \mathrm{~F}$ (5'-GCCGCRAGGTGAAAMCTA-3') and Micr 431R (5'-AATCCAAARACCTTCCTCCC-3') (Rinta-Kanto et al., 2005), the amplification of Microcystis-specific 16S rRNA gene was conducted under the following conditions: $95^{\circ} \mathrm{C}$ for $10 \mathrm{~min}$, followed by 45 cycles of $95^{\circ} \mathrm{C}$ for $10 \mathrm{~s}, 55^{\circ} \mathrm{C}$ for $30 \mathrm{~s}$ and $72^{\circ} \mathrm{C}$ for $30 \mathrm{~s}$. The PCR products were gel-purified and cloned into the pGEM-T vector (Promega) following the manufacturer's instructions. Inserts in the clones were confirmed through PCR using the specific primers above and subsequently electrophoresed. One positive plasmid containing each target gene was used as the qRT-PCR standard. The plasmid DNA was diluted 10 times to yield the standard curve. The concentrations of the diluted plasmid DNA ranged from $10^{8}$ to $10^{3}$ copies per microliter, the log of which has a linear relationship with the cycles of threshold (CT value). Melting curve analysis of the PCR products was conducted to assess reaction specificity and to determine the melting point of the amplification products. The target copy numbers of each sample were calculated from the standard curves, and the ratios between the colonyassociated bacteria and Microcystis were calculated from the copy numbers.

\section{PCR-denaturing gradient gel electrophoresis (DGGE)}

PCR amplifications were performed with the primers $341 f$ (5'-CCTACGGGAGGCAGCA-3') with a 40 bp GCclamp (5'-CGCCCGCCGCGCGCGGCGGGCGGGGCGGGGGCACGGGGGG) attached to its 5' end and 518r 
Table 1. The monthly DO, pH and concentrations of TN, TP and phycocyanin in the surface water during the decline of Microcystis bloom in Meiliang bay of Lake Taihu.

\begin{tabular}{|c|c|c|c|c|}
\hline & October 2009 & November 2009 & December 2009 & January 2010 \\
\hline$\overline{\mathrm{DO}\left(\mathrm{mg} . \mathrm{L}^{-1}\right)}$ & 8.4 & 11.06 & 13.22 & 12.59 \\
\hline $\mathrm{pH}$ & 8.47 & 8.34 & 8.31 & 8.51 \\
\hline $\mathrm{TN}\left(\mathrm{mg} . \mathrm{L}^{-1}\right)$ & 1.35 & 2.21 & 2.64 & 3.73 \\
\hline $\mathrm{TP}\left(\mathrm{mg} . \mathrm{L}^{-1}\right)$ & 0.05 & 0.11 & 0.08 & 0.11 \\
\hline Phycocyanin $\left(\mu \mathrm{g} . \mathrm{L}^{-1}\right)$ & 57.89 & 25.40 & 11.65 & 2.13 \\
\hline
\end{tabular}

(5'-ATTACCGCGGCTGCTG-3') (Muyzer et al., 1993). The $50 \mu \mathrm{L}$ PCR mixture contained $0.2 \mu \mathrm{M}$ of each primer, $1 \times$ PCR buffer (without $\mathrm{Mg}^{2+}$ ), $2.25 \mathrm{mM}$ of $\mathrm{MgCl}_{2}$, $0.8 \mathrm{mM}$ of deoxynucleotide triphosphates, $2 \mathrm{U}$ of DNA Taq polymerase (Takara, Japan) and $1 \mu \mathrm{L}$ of template DNA, which was similar to that analyzed with quantitative PCR. The amplification program consisted of an initial denaturation step at $94^{\circ} \mathrm{C}$ for $5 \mathrm{~min}$, followed by 20 cycles of $1 \mathrm{~min}$ at $94{ }^{\circ} \mathrm{C}, 1 \mathrm{~min}$ at $65-56{ }^{\circ} \mathrm{C}$ (decreasing by $0.5^{\circ} \mathrm{C}$ every cycle) and $1 \mathrm{~min}$ at $72^{\circ} \mathrm{C}$, then 10 additional cycles at $94{ }^{\circ} \mathrm{C}$ for $1 \mathrm{~min}, 55^{\circ} \mathrm{C}$ for $1 \mathrm{~min}$ and $72^{\circ} \mathrm{C}$ for $1 \mathrm{~min}$. The tubes were then incubated for $10 \mathrm{~min}$ at $72^{\circ} \mathrm{C}$. PCRs were performed in Bio-Rad thermal cyclers, and the PCR products were inspected on $1.2 \%(\mathrm{w} / \mathrm{v})$ agarose gels followed by goldview staining.

DGGE was performed with the DGGE-2001 system (CBS Scientific). The PCR products were directly applied onto $8 \%(\mathrm{w} / \mathrm{v})$ polyacrylamide gels containing a denaturing gradient from 40 to $70 \%(100 \%$ denaturant corresponded to $7 \mathrm{M}$ urea and $40 \%(\mathrm{v} / \mathrm{v})$ formamide). Electrophoresis was performed in $1 \times$ TAE $(20 \mathrm{mM}$ Trisacetate, $\mathrm{pH} 7.4,10 \mathrm{mM}$ acetate and $0.5 \mathrm{mM}$ disodium EDTA) at $60{ }^{\circ} \mathrm{C}$ for $16 \mathrm{~h}$ at $75 \mathrm{~V}$. After electrophoresis, the gels were stained in SYBR Green I (1:10000 dilution; Molecular Probes) for $30 \mathrm{~min}$ and photographed using Bio-Rad gel explorer. The DGGE band position and intensity were determined using Quantity One software version 4.6 (Bio-Rad) and manually modified. The pairwise similarity values were performed based on the Jaccard's coefficient that was calculated as follows: $J=$ $N_{\mathrm{AB}} /\left(N_{\mathrm{A}}+N_{\mathrm{B}}-N_{\mathrm{AB}}\right)$ where $N_{\mathrm{AB}}$ is the number of bands present in lanes $\mathrm{A}$ and $\mathrm{B}$, and $N_{\mathrm{A}}$ and $N_{\mathrm{B}}$ are the total number of bands in lanes $\mathrm{A}$ and $\mathrm{B}$, respectively. Cluster analysis of DGGE fingerprints was conducted by the unweighted pair group with mathematical averages (UPGMA) using the program MVSP version 3.1 (Kovach Computing Services).

\section{Clone library}

One representative sample of every month was selected to estimate changes in the diversity of the associated bacteria. In these lanes, except for the most dominant bands derived from Microcystis (indicated with an arrow), which were sequenced separately, other bands in the same lane were excised from the gel using a sterile scalpel, collected together and resuspended in $500 \mu \mathrm{L}$ of sterile Milli-Q water overnight at $4{ }^{\circ} \mathrm{C}$. Excised DNA was then re-amplified using primers $341 \mathrm{f}$ and $518 \mathrm{r}$, as previously described. The PCR products were ligated into the pGEM-T vector (Promega, Germany) and transformed into competent DH5 $\alpha$ cells. Approximately 30 positive clones in each clone library were selected and sequenced using the an ABI Bigdye 3.1 Terminator cycle sequencing kit (PerkinElmer Inc.) and an ABI 3730x1 DNA Analyzer with T7 primer at the Shanghai Sangon Biological Engineering Technology Limited Company, China. Sequences with $97 \%$ sequence similarity were grouped in operational taxonomic units (OTUs). One representative sequence from each group was selected for phylogenetic analysis. These sequences were then compared with $16 \mathrm{~S}$ rRNA sequences available in the National Center for Biotechnology Information database using BLAST search. In addition, the taxonomic affiliation of the partial 16S rRNA sequences was analyzed using the RDP classifier tool (http://rdp.cme.msu.edu/classifier) to confirm the taxonomic assignments.

The partial sequences of $16 \mathrm{~S}$ rRNA genes obtained in this study were deposited in GenBank with accession numbers: HQ902591-HQ902629.

\section{Results \\ Physicochemical variables and relative abundance of bacteria associated with Microcystis}

During the sampling period, the DO and TN concentrations increased, whereas the $\mathrm{pH}$ and TP fluctuated. An obvious decline in phycocyanin concentration was observed (Tab. 1). The water temperature decreased gradually, from $20^{\circ} \mathrm{C}$ to approximately $4{ }^{\circ} \mathrm{C}$ (Fig. 1). Results of the qRT-PCR analysis of the samples during the decline period of Microcystis bloom are presented in Figure 1. The quotients between copy numbers of colony-associated bacteria and that of Microcystis varied from $5.3 \pm 1.6$ to $0.1 \pm 0.1$. The maximum bacterial quotient was observed at the beginning of the decline period and then gradually decreased along with bloom decline, despite slight variations.

\section{Community structure based on DGGE profile analysis}

Different DGGE fingerprint patterns reflected changes in the associated bacterial community compositions (Fig. 2). Cluster analysis of the DGGE profiles grouped 


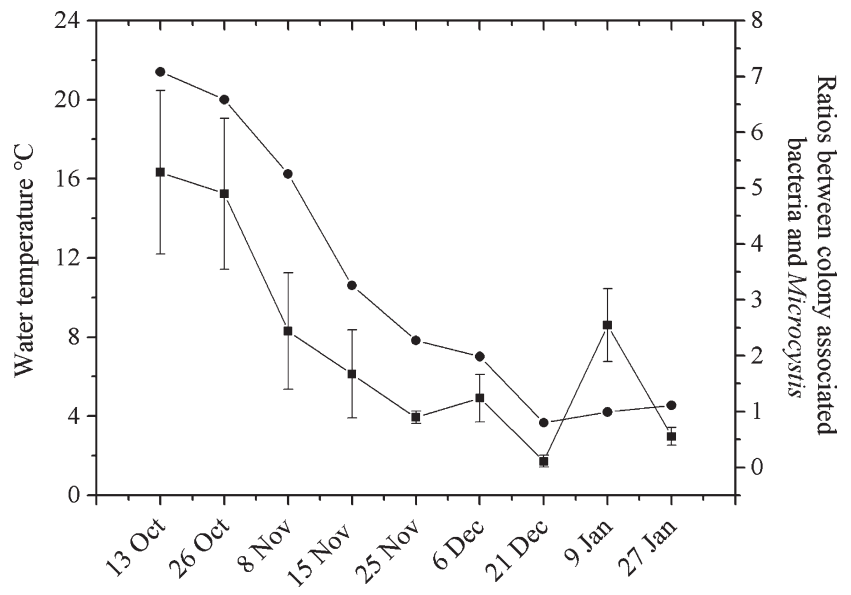

Fig. 1. Water temperature $(\bullet)$ on the sampling date, and the ratios between copy numbers of colony-associated bacteria and that of Microcystis ( $\boldsymbol{\square})$ in each sample estimated using the quantitative PCR assays. Error bars are the standard errors calculated from the mean of the three replicates.

the bacterial communities into two major clusters (Fig. 3). Cluster 1 was composed of bacterial communities associated with the Microcystis colonies collected before 6 December at a water temperature of $7{ }^{\circ} \mathrm{C}$, whereas Cluster 2 was composed of those collected after 21 December at a water temperature of $4{ }^{\circ} \mathrm{C}$. Most of the bacterial communities associated with Microcystis colonies collected on the nearby dates were clustered together.

\section{Clone analyses of bacterial communities}

The most dominant bands (arrows in Fig. 2) in lanes 13 Oct, 8 Nov, 21 Dec and 27 Jan were excised and sequenced. Sequence analysis revealed that they originated from cyanobacteria. Other bands in these four lanes were excised, mixed and used to construct four clone libraries. Approximately 20-30 clones in each clone library were sequenced. Based on sequence similarity, they were sorted into 5, 12, 6 and 12 OTUs. The sequencing analysis is listed in Table 2. Most sequences have high similarities $(98-100 \%)$ to the partial bacterial 16S rRNA gene sequences retrieved from GenBank. The taxonomic assignment according to BLAST search was consistent with that analyzed using an RDP II classifier. All these sequences were related to members of Alphaproteobacteria, Gammaproteobacteria and Bacteroidetes phyla. Gammaproteobacteria and Bacteroidetes were the most abundant. Additionally, several cyanobacterial sequences were detected. The clones from the clone library in October 2009 belonged to five OTUs. Among the OTUs, one (Oct1, affiliated with Aeromonas sp.) occurred with the highest frequency (19/30). OTU Oct4, which was affiliated with Rhodobacter sp., occurred at a frequency of $3 / 30$, whereas Oct 2 and Oct5 belonged to Shewanella sp. and Aeromonas sp. and were dominant in this clone library.

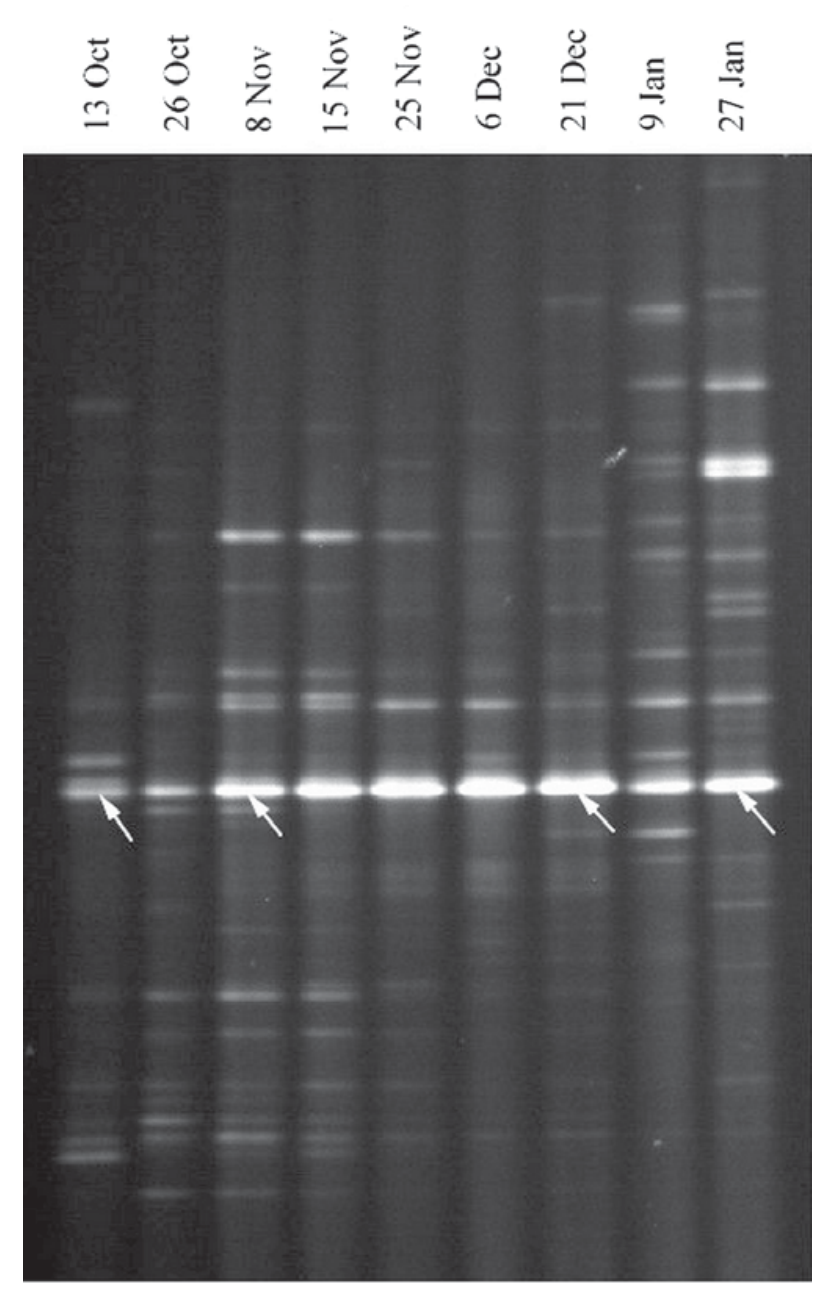

Fig. 2. DGGE profiles of 16S rRNA gene fragments of bacterial communities associated with Microcystis colonies.

For the clones obtained from the clone library in November 2009, OTUs Nov5, which included 6 of 25 clones, and Nov8 belonged to Aeromonas sp. Four OTUs, Nov6 (3 clones), Nov4 (2 clones), Nov10 (1 clone) and Nov9 (1 clone), were inferred to be members of the group of Bacteroidetes. OTU Nov3 (4 clones) was related to Gammaproteobacteria, whereas OTU Nov1 including 5 of 25 clones, was related to Shewanella sp. OTUs Nov11, Nov2 and Nov7 were related to Phenylobacterium sp., Pseudanabaena sp. and Aquamonas sp., respectively.

Regarding the clones in December 2009, six OTUs were observed. OTU Dec1 was related to Rhodobacter sp. (2 clones), and OTUs Dec2 and Dec6 were related to Aeromonas veronii (5 clones). OTU Dec3 belonged to cyanobacteria. OTU Dec4 was grouped with Shewanella sp. (7 clones), whereas OTUs Dec5 (1 clones) and Dec6 (4 clones) were grouped within Erythrobacter sp. and Bacteroidetes, respectively.

The clones from the clone library in January 2010 were also phylogenetically diverse. Eighteen clones belonging to five OTUs (Jan1, Jan2, Jan6, Jan11 and Jan12) were affiliated with Shewanella sp. Ten clones belonging to two OTUs (Jan4 and Jan7) were related to Pseudomonas sp. 


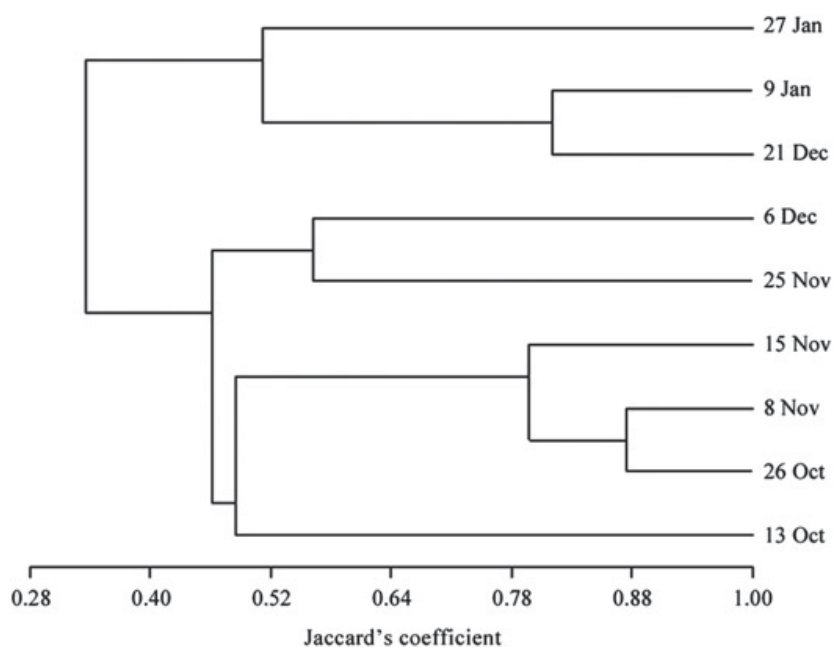

Fig. 3. Dendrogram constructed by UPGMA cluster analysis of bacterial communities associated with Microcystis colonies based on the DGGE profile.

Two OTUs (Jan3 and Jan10) belonged to Bacteroidetes. Three OTUs, Jan5, Jan8 and Jan9, belonged to Sporocytophaga sp., Aeromonas sp. and Bradyrhizobium sp., respectively. Shewanella sp. was dominant in this clone library.

Clones related to Aeromonas sp. and Shewanella sp. were detected in all four clone libraries. A change in the dominant species from Aeromonas sp. in October 2009 to Shewanella sp. in January 2010 was observed.

\section{Discussion}

The bacteria associated with Microcystis are sensitive to changes in the biochemical characteristics of their host. Changes in the bacterial community reflect the changes in physicochemical conditions within the colonies. To reveal the decline of Microcystis, the study therefore focused on the bacteria associated with Microcystis colonies.

The obvious decline in phycocyanin concentration coincide with the decrease of temperature, indicated the decline of Microcystis bloom. The DO and TN concentrations were influenced by this process. A decreasing trend in the ratios between colony-associated bacteria and Microcystis was observed (Fig. 1). Largely, the buoyant Microcystis colonies collected were the surviving colonies of the water population when the temperature decreased, indicating that the remaining integrated Microcystis colonies in the pelagic water at low temperature were more resistant to colonization. Brunberg (1995) demonstrated that colonies with different pre-histories and ages have different resistances to bacterial attack and decomposition. In addition, low temperature may be another reason for the declining number of mucilage bacteria, and would be propitious to the survival of Microcystis through the cold winter.

Cluster analysis indicates that most of the Microcystis colonies collected showed similar bacterial community structures (Fig. 3). Samples were grouped according to their sampling date. During the decline of cyanobacterial bloom, the structure of the associated bacterial assemblage was influenced by water temperature, which is an important environmental factor for the decline of Microcystis colonies. The algae-derived organic matters were influenced by temperature (Van der Westhuizen et al., 1986; Davis et al., 2009), which may inversely influence the associated bacterial community.

To reveal the diversity of the colony-associated bacteria, PCR product amplified using the primers $27 \mathrm{f}$ and $1492 \mathrm{r}$ was used to construct clone libraries for sequencing analysis. However, because of the low proportions of the associated bacteria in the colonies, more than $80 \%$ of the sequences originated from Microcystis, which could also be amplified using the two primers. To eliminate the interference of Microcystis, previously described methods were used. DGGE analysis shows that re-amplification of the mixed bands did not influence the band patterns of the bacterial community (data not shown).

The dominance of Gammaproteobacteria and Bacteroidetes associated with declining Microcystis colonies was observed in this study. This is different from the diverse bacteria groups, such as Alphaproteobacteria, Gammaproteobacteria, Bacteroidetes, Actinobacteria and Firmicutes, which are associated with Microcystis colonies during the vigorous period according to a previous study (Shi et al., 2010). The study performed by Wu et al. (2007) on the bacterial community in the water column during the course of the cyanobacterial bloom suggested that species richness slightly decreased from July to September. Bacteroidetes, which are chemo-organotrophic bacteria abundant in cyanobacterial blooms (Eiler and Bertilsson, 2004), can efficiently degrade a variety of high-molecularmass fraction DOM and other compounds, such as protein, cellulose, pectin and chitin (Kirchman, 2002). Bacteroidetes can dominate the microbial community after viral lysis of the filamentous cyanobacteria (Van Hannen et al., 1999). These populations may be responsible for the microbe-mediated decomposition of Microcystis colonies during the decline period.

Majority of the phylotypes of the colony-associated bacteria belonged to Gammaproteobacteria. An increase in the proportion of Gammaproteobacteria in the decline of the bloom was also observed in Xuanwu Lake (Zheng et al., 2008). The dominant bacteria were Aeromonas spp., which are opportunistic animal and human pathogens, and Shewanella spp., which are capable of remineralization of many organic materials. Both micro-organisms were not observed to inhabit Microcystis colonies in summer during the bloom (Shi et al., 2010). Aeromonas has been found in wastewater, chlorinated water supplies, surface water and ground water, as well as estuarine and marine environments (Borrell et al., 1998; Pettibone, 1998; Bianucci et al., 2001). Some bacterial strains of these species are cold-adapted (Singh et al., 2000). In addition, the Aeromonas genera, which may cause adverse effects to the health of humans and animals, were found to be 
Table 2. BLAST analysis of the Microcystis bloom-derived 16S rDNA fragments retrieved from the DGGE gel. The Oct-M, Nov-M, Dec-M and Jan-M were sequences from bands that were indicated with arrows in Figure 2. In addition, the RDP classifier tool was also used to confirm the taxonomic assignments.

\begin{tabular}{|c|c|c|c|c|c|}
\hline $\begin{array}{l}\text { Clone library } \\
\text { and band }\end{array}$ & OTU & $\begin{array}{l}\text { Accession } \\
\text { number }\end{array}$ & Closest relative (accession number) & $\begin{array}{c}\text { Similarity } \\
(\%)\end{array}$ & Taxon assignment \\
\hline \multirow[t]{5}{*}{ October 2009} & Oct1 & HQ902591 & Aeromonas sp. A254 (HQ413137) & 100 & Gammaproteobacteria \\
\hline & Oct2 & HQ902592 & $\begin{array}{l}\text { Shewanella xiamenensis strain } \\
\text { CAIM } 1494 \text { (HM584096) }\end{array}$ & 100 & Gammaproteobacteria \\
\hline & Oct3 & HQ902593 & Aeromonas sp. 5A12S1 (HQ246266) & 100 & Gammaproteobacteria \\
\hline & Oct4 & HQ902594 & Rhodobacter sp. RCRI19 (HQ392507) & 100 & Alphaproteobacteria \\
\hline & Oct5 & HQ902595 & Shewanella sp. BAM79 (AB300600) & 100 & Gammaproteobacteria \\
\hline \multirow[t]{12}{*}{ November 2009} & Nov1 & HQ902596 & Shewanella sp. POL1 (FN870751) & 100 & Gammaproteobacteria \\
\hline & Nov2 & HQ902597 & Pseudanabaena sp. 0tu30s18 (AM259268) & 100 & Cyanobacteria \\
\hline & Nov3 & HQ902598 & $\begin{array}{l}\text { Uncultured gammaproteobacterium clone } \\
\text { MEsu06cnp11C8 (FJ828374) }\end{array}$ & 100 & Gammaproteobacteria \\
\hline & Nov4 & HQ902599 & $\begin{array}{l}\text { Uncultured bacteroidetes bacterium clone } \\
\text { hsh-8-46 (GU323652) }\end{array}$ & 98 & Bacteroidetes \\
\hline & Nov5 & HQ902600 & Aeromonas veronii strain CL0901 (HM240294) & 100 & Gammaproteobacteria \\
\hline & Nov6 & HQ902601 & $\begin{array}{l}\text { Uncultured bacteroidetes bacterium clone } \\
\text { hsh-8-46 (GU323652) }\end{array}$ & 100 & Bacteroidetes \\
\hline & Nov7 & HQ902602 & $\begin{array}{l}\text { Uncultured Aquamonas sp. clone } \\
\text { IG1bG02 (FJ718009) }\end{array}$ & 97 & Betaproteobacteria \\
\hline & Nov8 & HQ902603 & Aeromonas sp. AKB-2008-HE40 (AM989223) & 100 & Gammaproteobacteria \\
\hline & Nov9 & HQ902604 & $\begin{array}{l}\text { Uncultured bacteroidetes bacterium clone } \\
\text { MEsu06cnp11H9 (FJ828426) }\end{array}$ & 98 & Bacteroidetes \\
\hline & Nov10 & HQ902605 & $\begin{array}{l}\text { Uncultured flexibacteraceae bacterium clone } \\
\text { Nitri_2_a2 (HM193113) }\end{array}$ & 94 & Bacteroidetes \\
\hline & Nov11 & HQ902606 & $\begin{array}{l}\text { Uncultured Phenylobacterium sp. clone } \\
\text { XZXXH71 (EU703427) }\end{array}$ & 100 & Alphaproteobacteria \\
\hline & Nov12 & HQ902607 & Uncultured bacterium clone GBII-64 (GQ441331) & 98 & unknown \\
\hline \multirow[t]{6}{*}{ December 2009} & Decl & HQ902608 & Rhodobacter sp. INCT285 (AB546235) & 99 & Alphaproteobacteria \\
\hline & Dec2 & HQ902609 & A. veronii strain CL0901 (HM240294) & 100 & Gammaproteobacteria \\
\hline & Dec3 & HQ902610 & Anabaena mendotae TAC584 (AB551482) & 99 & Cyanobacteria \\
\hline & Dec4 & HQ902611 & Shewanella sp. S7 (FN994185) & 100 & Gammaproteobacteria \\
\hline & Dec5 & HQ902612 & Erythrobacter sp. H301 (HQ622544) & 100 & Alphaproteobacteria \\
\hline & Dec6 & HQ902613 & A. veronii strain NS01(GQ141742) & 98 & Gammaproteobacteria \\
\hline \multirow[t]{12}{*}{ January 2010} & Jan 1 & HQ902614 & Shewanella sp. S7 (FN994185) & 98 & Gammaproteobacteria \\
\hline & $\operatorname{Jan} 2$ & HQ902615 & $\begin{array}{l}\text { Uncultured Shewanella sp. partial 16S rRNA gene, } \\
\text { clone OuchyA-69 (FN679137) }\end{array}$ & 100 & Gammaproteobacteria \\
\hline & Jan3 & HQ902616 & $\begin{array}{l}\text { Uncultured Flavobacterium sp. clone } \\
\text { L6B-142 (GU000476) }\end{array}$ & 100 & Bacteroidetes \\
\hline & Jan 4 & HQ902617 & Pseudomonas sp. PsS31 (HM627624) & 100 & Gammaproteobacteria \\
\hline & Jan5 & HQ902618 & $\begin{array}{l}\text { Uncultured Sporocytophaga sp. clone } \\
\text { Cat004C_H10 (EU572368) }\end{array}$ & 100 & Bacteroidetes \\
\hline & Jan6 & HQ902619 & Shewanella sp. IPC4 (HQ108170) & 100 & Gammaproteobacteria \\
\hline & Jan7 & HQ902620 & Pseudomonas sp. FD6 (HM768205) & 100 & Gammaproteobacteria \\
\hline & Jan8 & HQ902621 & $\begin{array}{l}\text { Aeromonas sobria partial 16S rRNA gene, } \\
\text { isolate LE } 76 \text { (FN908438) }\end{array}$ & 100 & Gammaproteobacteria \\
\hline & Jan9 & HQ902622 & Bradyrhizobium sp. Z2-YC6857 (GQ369125) & 100 & Alphaproteobacteria \\
\hline & Jan 10 & HQ902623 & $\begin{array}{l}\text { Uncultured bacteroidetes bacterium clone } \\
\text { MEsp06cnp11H3 (FJ828248) }\end{array}$ & 95 & Bacteroidetes \\
\hline & Jan 11 & HQ902624 & S. xiamenensis strain H3 (HQ418493) & 100 & Gammaproteobacteria \\
\hline & Jan 12 & HQ902625 & Shewanella baltica (AJ000216) & 100 & Gammaproteobacteria \\
\hline \multirow[t]{4}{*}{ Bands } & Oct-M & HQ902626 & Microcystis aeruginosa UADFM7 (HM854736) & 99 & Cyanobacteria \\
\hline & Nov-M & HQ902627 & M. aeruginosa UADFM7 (HM854736) & 98 & Cyanobacteria \\
\hline & Dec-M & HQ902628 & M. aeruginosa UADFM7 (HM854736) & 100 & Cyanobacteria \\
\hline & Jan-M & HQ902629 & M. aeruginosa UADFM7 (HM854736) & 100 & Cyanobacteria \\
\hline
\end{tabular}

associated with cyanobacterial blooms (Berg et al., 2009; Kormas et al., 2010). Evidence for Aeromonas chemotaxis to cyanobacteria (Aphanizomenon flos-aquae) was found by Kangatharalingam et al. (1991). The crude microcystin extracted from Microcystis could improve the change of Aeromonas from viable but non-culturable state to culturable state (Pan et al., 2008). The presence of Aeromonas sp. may prevent Microcystis colonies from becoming prey 
to zooplankton suggesting a potential increased risk for public health caused by cyanobacterial blooms. Shewanella $\mathrm{sp}$. is a common aquatic Gram-negative bacterium with a worldwide distribution. It is capable of thriving at low temperatures and plays an important role in the re-mineralization of organic material in water column (Brettar and Höfle, 1993). In addition, Shewanella putrefaciens displays positive chemotaxis to most electron acceptors utilized for anaerobic growth (Nealson et al., 1995). A positive effect of Shewanella sp. was found on the growth of Nodularia spumigena, with which it coexists in the Baltic Sea (Salomon et al., 2003). The ability of Shewanella sp. to re-mineralize organic materials may be helpful in prolonging Microcystis blooms.

Other phylotypes are affiliated with genera, such as Sphingomonas, Rhodobacter and Bradyrhizobium (Alphaproteobacteria), Flavobacterium (Bacteroidetes), or Pseudomonas (Gammaproteobacteria). These genera are also associated with Microcystis spp. during the vigorous period of bloom (Shi et al., 2010). Bacteria related to Sphingomonas or Flavobacterium are capable of degrading cyanobacterial toxins or other problematic organic complex compounds (Valeria et al., 2006; Berg et al., 2009).

Although bacterial community structure changed along with the bloom decline, persistent associations of Aeromonas spp. and Shewanella spp. with Microcystis colonies were observed. A possible explanation for the appearance of these distinct bacteria is the release of different extracellular compounds from the phytoplankton cell during the period of the bloom decline. For example, transparent exopolymer particles (TEP), composed of extracellular polysaccharide, dead algal cells and so on, are frequently formed during the decline of diatom and cyanobacterial bloom (Schuster and Herndl, 1995; Grossart and Simon, 1997), and many TEP are considered as excellent substrates for bacteria (Berman and VinerMozzini, 2001). However, the extracellular compounds from buoyant Microcystis cells during the bloom decline period are not very clear and need to be studied in the future. The ability of these bacteria to adapt to low temperatures could be another reason for their dominance. However, the mechanisms of these associations still need further study.

In conclusion, buoyant Microcystis colonies on the water surface harbor distinct bacterial communities. To our knowledge, this is the first report on microbial communities associated with buoyant Microcystis colonies, which would take an important role during the next summer bloom (Verspagen et al., 2005), during the decline period of annual freshwater bloom. qRT-PCR revealed a gradual decrease in the ratio of bacteria associated with Microcystis colonies, indicating that Microcystis colonies remaining buoyant on the water surface are resistant to bacterial colonization. The colony-associated bacteria are dominated by Gammaproteobacteria and Bacteroidetes. Potential pathogens, such as Aeromonas sp. and Shewanella sp., are also present. These bacteria may facilitate the survival of the Microcystis colonies. They also highlight the potential ecological importance of the decline period of cyanobacterial blooms to the safety of lake water.

Acknowledgements. The authors are grateful to the anonymous reviewers for their valuable comments and constructive reviews of this paper. We also thank our colleagues in our laboratory for their help during this study. This research was supported by National Basic Research Program of China (973 Program, 2008CB418000), National Natural Science Foundation of China (No. 20807043) and China Postdoctoral Science Foundation (No. 20090461147).

\section{References}

Amemiya Y., Kato K., Okino T. and Nakayama O., 1990. Changes in the chemical composition of carbohydrates and proteins in surface water during a bloom of Microcystis in Lake Suwa. Ecol. Res., 5, 153-162.

Asai R., Horiguchi Y., Yoshida A., McNiven S., Tahira P., Ikebukuro K., Uchiyama S., Masuda Y. and Karube I., 2001. Detection of phycobilin pigments and their seasonal change in Lake Kasumigaura using a sensitive in situ fluorometric sensor. Anal. Lett., 34, 2521-2533.

Bell W.H. and Mitchell R., 1972. Chemotactic and growth responses of marine bacteria to algal extracellular products. Biol. Bull., 143, 264-277.

Berg K.A., Lyra C., Sivonen K., Paulin L., Suomalainen S., Tuomi P. and Rapala J., 2009. High diversity of cultivable heterotrophic bacteria in association with cyanobacterial water blooms. ISME J., 3, 314-325.

Berman T. and Viner-Mozzini Y., 2001. Abundance and characteristics of polysaccharide and proteinaceous particles in Lake Kinneret. Aquat. Microb. Ecol., 24, 255-264.

Bianucci F., Bernagozzi M., Sacchetti R. and Bisbini P., 2001. Determination of Aeromonas spp. and Pseudomonas spp. in chlorinated water supply. Ann. Ig., 13, 185-189.

Borrell N., Figueras M.J. and Guarro J., 1998. Phenotypic identification of Aeromonas genomospecies from clinical and environmental sources. Can. J. Microbiol., 44, 103-108.

Bostroëm B., Pettersson A.K. and Ahlgren I., 1989. Seasonal dynamics of a cyanobacteria-dominated microbial community in surface sediments of a shallow eutrophic lake. Aquat. Sci., 51, 153-178.

Brettar I. and Höfle M.G., 1993. Nitrous oxide producing heterotrophic bacteria from the water column of the Baltic sea: abundance and molecular identification. Mar. Ecol. Prog. Ser., 94, 253-265.

Brunberg A.K., 1995. Microbial activity and phosphorus dynamics in eutrophic lake sediments enriched with Microcystis colonies. Freshw. Biol., 33, 541-555.

Brunberg A.K., 1999. Contribution of bacteria in the mucilage of Microcystis spp. (Cyanobacteria) to benthic and pelagic bacterial production in a hypereutrophic lake. FEMS Microbiol. Ecol., 29, 13-22.

Casamatta D. and Wickstrom C., 2000. Sensitivity of two disjunct bacterioplankton communities to exudates from the cyanobacterium Microcystis aeruginosa. Microb. Ecol., 41, 64-73.

Davis T.W., Berry D.L., Boyer G.L. and Gobler C.J., 2009. The effects of temperature and nutrients on the growth and 
dynamics of toxic and non-toxic strains of Microcystis during cyanobacteria blooms. Harmful Algae, 8, 715-725.

Eiler A. and Bertilsson S., 2004. Composition of freshwater bacterial communities associated with cyanobacterial blooms in four Swedish lakes. Environ. Microbiol., 6, 1228-1243.

Grossart H.-P. and Simon M., 1997. Formation of macroscopic organic aggregates (lake snow) in a large lake: The significance of transparent exopolymer particles, phytoplankton, and zooplankton. Limnol. Oceanogr., 42, 1651-1659.

Jin X. and Tu Q., 1990. The standard methods for observation and analysis of lake eutrophication (2nd edn), China Environmental Science Press, Beijing (in Chinese).

Kangatharalingam N., Wang L. and Priscu J.C., 1991. Evidence for bacterial chemotaxis to cyanobacteria from a radioassay technique. Appl. Environ. Microbiol., 57, 2395-2398.

Kirchman D.L., 2002. The ecology of Cytophaga-Flavobacteria in aquatic environments. FEMS Microbiol. Ecol., 39, 91-100.

Kormas K.A., Vardaka E., Moustaka-Gouni M., Kontoyanni V., Petridou E., Gkelis S. and Neofitou C., 2010. Molecular detection of potentially toxic cyanobacteria and their associated bacteria in lake water column and sediment. World J. Microbiol. Biotechnol., 26, 1473-1482.

Manage P.M., Kawabata Z. and Nakano S.I., 2000. Algicidal effects of the bacterium Alcaligenes denitrificans on Microcystis spp. Aquat. Microb. Ecol., 22, 111-117.

Muyzer G., de Waal E.C. and Uitterlinden A.G., 1993. Profiling of complex microbial populations by denaturing gradient gel electrophoresis analysis of polymerase chain reaction-amplified genes coding for 16S rRNA. Appl. Environ. Microbiol., $59,695-700$.

Nealson K.H., Moser D.P., and Saffarini D.A., 1995. Anaerobic electron acceptor chemotaxis in Shewanella putrefaciens. Appl. Environ. Microbiol., 61, 1551-1554.

Pan G., Hu Z., Lei A. and Li S., 2008. Effect of crude microcystin on the viable but non-culturable state of Aeromonas sobria in aquatic environment. J. Lake Sci., 20, 105-109 (in Chinese).

Pearl H.W., 1988. Growth and reproductive strategies of freshwater bluegreen algae (cyanobacteria). In: Sandgren C.D. (ed.), Growth and reproductive strategies of freshwater phytoplankton, Cambridge University Press, Cambridge, 261-315.

Pettibone G.W., 1998. Population dynamics of Aeromonas spp. in an urban river watershed. J. Appl. Microbiol., 85, 723-730.

Rashidan K.K. and Bird D.F., 2001. Role of predatory bacteria in the termination of a cyanobacterial bloom. Microb. Ecol., 41, 97-105.

Reynolds C.S., 2006. The ecology of phytoplankton, Cambridge University Press, Cambridge, 384 p.

Reynolds C.S., Jaworski G.H.M., Cmiech H.A. and Leedale G.F., 1981. On the annual cycle of the blue-green alga Microcystis aeruginosa Kutz Emend Elenkin. Proc. R. Soc. Lond. Ser. B., 293, 419-477.

Riemann L. and Winding A., 2001. Community dynamics of free-living and particle-associated bacterial assemblages during a freshwater phytoplankton bloom. Microb. Ecol., 42, 274-285.

Rinta-Kanto J.M., Ouellette A.J., Boyer G.L., Twiss M.R., Bridgeman T.B. and Willhelm S.W., 2005. Quantification of toxic Microcystis spp. during the 2003 and 2004 blooms in western Lake Erie using quantitative real-time PCR. Environ. Sci. Technol., 39, 4198-4205.
Rooney-Varga J.N., Giewat M.W., Savin M.C., Sood S., LeGresley M. and Martin J.L., 2005. Links between phytoplankton and bacterial community dynamics in a coastal marine environment. Microb. Ecol., 49, 163-175.

Salomon P.S., Janson S. and Granéli E., 2003. Molecular identification of bacteria associated with filaments of Nodularia spumigena and their effect on the cyanobacterial growth. Harmful Algae, 2, 261-272.

Schuster S. and Herndl G.J., 1995. Formation and significance of transparent exopolymeric particles in the northern Adriatic Sea. Mar. Ecol. Prog. Ser., 124, 227-236.

Shi L.M., Cai Y.F., Yang H.L., Xing P., Li P.F., Kong L.D. and Kong F.X., 2009. Phylogenetic diversity and specificity of bacteria associated with Microcystis aeruginosa and other cyanobacteria. J. Environ. Sci., 21, 1581-1590.

Shi L.M., Cai Y.F., Wang X.Y., Li P.F., Yu Y. and Kong F.X., 2010. Community structure of bacteria associated with Microcystis colonies from cyanobacterial blooms. J. Freshw. Ecol., 25, 193-203.

Sigee D.C., 2005. Freshwater microbiology, John Wiley and Sons Ltd., West Sussex, England, 524 p.

Singh L., Sairam M., Agarwal M.K. and Alam S.I., 2000. Characterization of Aeromonas hydrophila strains and their evaluation for biodegradation of night soil. World J. Microbiol. Biotechnol., 16, 625-630.

Steppe T.F., Olson J.B., Paerl H.W., Litaker R.W. and Belnap J., 1996. Consortial $\mathrm{N}_{2}$ fixation: a strategy for meeting nitrogen requirements of marine and terrestrial cyanobacterial mats. FEMS Microbiol. Ecol., 21, 149-156.

Tillett D. and Neilan B.A., 2000. Xanthogenate nucleic acid isolation from cultured and environmental cyanobacteria. J. Phycol., 36, 251-258.

Valeria A.M., Ricardo E.J., Stephan P. and Alberto W.D., 2006. Degradation of microcystin-RR by Sphingomonas sp. CBA4 isolated from San Roque reservoir (Córdoba-Argentina). Biodegradation, 17, 447-455.

Van Hannen E.J., Zwart G., Van Agterveld M.P., Gons H.J., Ebert J. and Laanbroek H.J., 1999. Changes in bacterial and eukaryotic community structure after mass lysis of filamentous cyanobacteria associated with viruses. Appl. Environ. Microbiol., 65, 795-801.

Van der Westhuizen A.J., Eloff J.N. and Krüger G.H.J., 1986. Effect of temperature and light intensity (fluence rate) on the composition of the toxin of the cyanobacterium Microcystis aeruginosa (UV-006). Arch. für Hydrobiol., 108, 145-154.

Verspagen J.M.H., Snelder E.O.F.M., Visser P.M., Johnk K.D., Ibelings B.W., Mur L.R. and Huisman J., 2005. Benthicpelagic coupling in the population dynamics of the harmful cyanobacterium Microcystis. Freshw. Biol., 50, 854-867.

Worm J. and Søndergaard M., 1998. Dynamics of heterotrophic bacteria attached to Microcystis spp. (Cyanobacteria). Aquat. Microb. Ecol., 14, 19-28.

Wu X., Xi W., Ye W. and Yang H., 2007. Bacterial community composition of a shallow hypertrophic freshwater lake in China, revealed by $16 \mathrm{~S}$ rRNA gene sequences. FEMS Microbiol. Ecol., 61, 85-96.

Zheng X.H., Xiao L., Ren J. and Yang L.Y., 2008. Variation of bacterial community composition in the outbreak and decline of Microcystis spp. bloom in Lake Xuanwu. Huan Jing Ke Xue, 29, 2956-2962 (in Chinese). 